\title{
PENGEMBANGAN KECERDASAN SPIRITUAL MELALUI MATA PELAJARAN PENDIDIKAN AGAMA ISLAM PADA PESERTA DIDIK MADRASAH ALIYAH
}

\author{
Irpan Maulana \\ Pascasarjana IAIN Syekh Nurjati Cirebon, Indonesia \\ E-mail :Irfanmaulana021995@gmail.com
}

\begin{abstract}
The Development of spiritual intelligence in the world of education is an investment in character that must be possessed by students. This is because of the increasingly widespread promiscuity which is a moral decline for our youth. Islamic Senior High School Manbaul Huda Cisambeng Palasah Majalengka is an educational institution that promotes spirituality through the process of hablu minAllah and bablu minannaas. For this reason, this research was conducted, which aims to reveal the development of spiritual intelligence through Islamic religious education subjects in the Islamic Senior High School Manbaul Huda Cisambeng Palasah Majalengka. In this study, the authors used a qualitative approach. By using a case study research model. While the methods used, namely observation, in-depth interviews, and documentation. The results showed that: (a) spiritual intelligence was pursued through Hablu MinAllah and Hablu Minannaas. (b) Islamic Religious Education subjects include Al-Qur'an's Hadith, Islamic creed, Jurisprudence, and Islamic Cultural History which are basically interrelated, filled and complemented. (c) the development of spiritual intelligence through Islamic Religious Education subjects in students which is done by using the teacher's approach as an example, the strategy is through the values of Islamic religious education and religious activities, the method used is culturing the students, so there are impacts and benefits for students.
\end{abstract}

Keywords: spiritual intelligence, Islamic religious education

\begin{abstract}
ABSTRAK
Pengembangan kecerdasan spiritual di dunia pendidikan merupakan penanaman karakter yang harus dimiliki oleh peserta didik. Hal ini dikarenakan semakin maraknya pergaulan bebas yang merupakan suatu kemerosotan moral bagi remaja kita. Madrasah Aliyah (MA) Manbaul Huda Cisambeng Palasah Majalengka merupakan lembaga pedidikan yang mengedepankan spiritualitas melalui proses hablu minAllah dan hablu minannaas. Untuk itulah penelitian ini dilakukan, yaitu bertujuan untuk mengungkapkan pengembangan kcerdasan spiritual melalui mata pelajaran pendidikan agama Islam di Madrasah Aliya (MA) Mabaul Huda Cisambeng Palasah Majalengka. Dalam penelitian ini, penulis menggunakan pendekatan kualitatif. Dengan menggunakan model penelitian studi kasus. Sedangkan metode yang digunakan, yaitu observasi, wawancara mendalam, dan dokumentasi. Hasil penelitian menunjukan bahwa: (a) kecerdasan spiritual ditempuh melalui Hablu MinAllah dan Hablu Minannaas. (b) mata pelajaran Pendidikan Agama Islam meliputi Al-Qur'an Hadits, Akidah Akhlak, Fikih, dan Sejarah Kebudayaan Islam yang pada dasarnya saling terkait, isi mengisi dan melengkapi. (c) pengembangan kecerdasan spiritual melalui mata pelajaran Pendidikan Agama Islam pada peserta didik yang dilakukan dengan mengunakan pendekatan guru sebagai tauladan, strateginya melalui nilai-nilai pedidikan agama Islam dan aktivitas keagamaan, metode yang digunakan adalah pemibasaan pada peserta didik, sehingga ada dampak dan manfaatnya bagi peserta didik.
\end{abstract}

Kata kunci : kecerdasan spiritual, pendidikan agama Islam.

Submitted May 13, 2020 | Revised Jun 16, 2020 | Accepted Jun 23, 2020 


\section{Pendahuluan}

Pendidikan merupakan segala daya upaya dan semua usaha untuk membuat masyarakat dapat mengembangkan potensi manusia agar memiliki kekuatan spiritual keagamaan, pengendalian diri, berkepribadian, memiliki kecerdasan, berakhlak mulia, serta memiliki keterampilan yang diperlukan sebagai anggota masyarakat dan warga negara. Di samping itu pendidikan merupakan usaha untuk membentuk manusia yang utuh lahir dan batin, cerdas, sehat, dan berbudi pekerti luhur.

Apakah praktek pendidikan yang ada belum mampu menyentuh secara keseluruhan, domain akal dan terutama menyentuh jiwa dan hati mereka, sehinggga terlihat orientasi pengembangan intelektual menjadi prioritas utama dari suatu pendidikan, dan tanpa diimbangi dengan kekuatan spiritual (Rahawai, 2016)

Pendidikan yang berlangsung di sekolah selama ini masih lebih menekankan pada pengembangan kecerdasan intelektual yang mementingkan kemampuan logika matematika dan bahasa. Di sekolah, anak-anak yang dikelompokkan sebagai anak cerdas ialah anak-anak yang pandai dalam matematika dan bahasa. Hal tersebut terjadi karena pandangan yang sempit tentang kecerdasan. Selama beberapa abad orang percaya bahwa kecerdasan intelektual merupakan satu-satunya kecerdasan yang dapat dikembangkan. Pandangan tentang kecerdasan tersebut sejak beberapa dekade ini telah berubah. Kecerdasan tidak bersifat tunggal melainkan jamak dan harus dikembangkan secara menyeluruh (Hasanah, 2016)

Berdasarkan hal di atas maka sangat penting untuk menerapkan pendidikan karakter kepada peserta didik karena pendidikan karakter disekolah sangat diperlukan. T. Lickona (1991) menekankan pentingnya tiga komponen karakter yang baik, bahwa karakter yang baik terdiri atas mengetahui kebaikan (knowing the good), mencintai atau menginginkan kebaikan (loving or desiring the good), dan melakukan kebaikan (acting the good). Oleh karena itu, cara membentuk karakter yang efektif adalah dengan melibatkan ketiga aspek tersebut (Komara, 2018). Walaupun dasar dari pendidikan karakter adalah di keluarga, pembentukan karakter siswa di sekolah bertumpu pada kurikulum. Menurut para ahli psikologi, beberapa nilai karakter dasar tersebut adalah: cinta kepada Allah dan ciptaann-Nya (alam dengan isinya), tanggung jawab, jujur, hormat dan santun, kasih sayang, peduli, dan kerjasama, percaya diri, kreatif, kerja keras, dan pantang menyerah, keadilan dan kepemimpinan; baik dan rendah hati, toleransi, cinta damai, dan cinta persatuan yang kesemuanya itu dapat di lakukan melalui penembangan kecerdasan spiritual peserta didik. Berdasarkan hal tersebut, maka sangat urgen untuk melakkan kajian secara lebih medalam mengenai pengembangan kecerdasan spiritual melalui mata pelajaran pendidikan agama Islam pada peserta didik di Madrasah Aliyah (MA) Manbaul Huda Cisambeng Palasah Majalengka.

Berdasarkan latar belakang masalah yang telah dijelaskan di atas, penulis merumuskan masalah-masalah yang ada dalam penelitian ini sebagai berikut: 1) Bagaimana kecerdasan spiritual di MA Manbaul Huda Cisambeng Palasah Majalengka?, 2) Bagaimana pembelajaran Pendidikan Agama Islam di MA Manbaul Huda Cisambeng Palasah Majalengka?, 3) Bagaimana pengembangan kecerdasan spiritul melalui mata pelajaran Pendidikan Agama Islam pada peserta didik di MA Manbaul Huda Cisambeng Palasah Majalengka?.

Dari rumusan masalah di atas, maka penulis mempunyai tujuan penelitian sebagai berikut: 1) Mengetahui kecerdasan spiritual di MA Manbaul Huda Cisambeng Palasah Majalengka. 2) Mengetahui pembelajaran Pendidikan Agama Islam di MA Manbaul Huda 
Cisambeng Palasah Majalengka. 3) Mengetahui pengembangan kecerdasan spiritul melalui mata pelajaran Pendidikan Agama Islam pada peserta didik di MA Manbaul Huda Cisambeng Palasah Majalengka.

\section{Metode Penelitian}

Bertitik tolak dari pemikiran dan permasalahan diatas, metodologi yang digunakan dalam penelitian ini adalah dengan pendekatan kualitatif, yakni strategi dan teknik penelitian yang digunakan untuk memahami masyarakat, masalah atau gejala dalam masyarakat dengan mengumpulkan sebanyak mungkin fakta mendalam, data disajikan dalam bentuk verbal, bukan dalam bentuk angka. Pendekatan kualitatif memiliki karakteristik alami (natural setting) sebagai sumber data langsung, deskriptif, proses lebih dipentingkan dari pada hasil, analisis dalam penelitian kualitatif cenderung dilakukan secara analisa induktif dan makna merupakan hal yang esesnsial. (Moleong, 2017). Maka, penelitian yang dilakukan oleh penulis di Madrasah Aliyah Manbaul Huda Cisambeng kecamatan Palasah kabupaten Majalengka ini termasuk penelitian yang bersifat naturalstik karena berdasarkan apa adanya pada kondisi yang sebenarnya terjadi di lingkungan sekolah Madrasah Aliyah Manbaul Huda Cisambeng kecamatan Palasah kabupaten Majalengka secara alamiah. Peneliti akan mengungkapkan hasil penelitian berdasarkan apa yang sedang dan akan dilakukan melalui kebijakan kepala sekolah Madrasah Aliyah Manbaul Huda Cisambeng kecamatan Palasah kabupaten Majalengka dalam rangka membina dan membentuk karakter pesrta didik melalui pengembangan kecerdasan spiritual peserta didiknya.

Penelitian ini merupakan metode studi kasus yang digunakan secara intensif, terinci dan mendalam dalam menggambarkan pengembangan kecedasan spiritual peserta didik melalui mata pelajaran pendidikan agama Islam di Madrasah Aliyah Manbaul Huda Cisambeng kecamatan Palasah kabupaten Majalengka.

Sumber data utama dalam penelitian ini adalah kata-kata dan tindakan, selebihnya adalah tambahan seperti dokumen dan lainnya. Dengan demikian sumber data dalam penelitian ini adalah kata-kata dan tindakan sebagai sumber utama, sedangkan sumber data tertulis, foto dan catatan tertulis adalah sumber data tambahan.

Pemilihan instrumen pengumpulan data tergantung pada beberapa faktor, yaitu teknik pengumpulan data dan karakter dari data yang dibutuhkan, pemilihan instrumen tergantung pula pada karakter dataya (Kurniawan, 2018). Instrmen penelitian yang dilakukan diantaranya adalah observasi, wawancara mendalam dan dokumentasi. Teknik analisis data yang digunakan dalam penelitian ini adalah mengacu pada konsep Milles \& Huberman (1992: 20) yaitu interactive model yang mengklasifikasikan analisis data dalam tiga langkah, yaitu : 1) Reduksi data, 2) Penyajian data, dan 3) Penarikan kesimpulan.

\section{Hasil dan Pembahasan}

1. Kecerdasan Spiritual

Danah Zohar dan Ian Marshall (2007) yang mengungkapkan bahwa SQ yang saya maksud adalah kecerdasan untuk menghadapi dan memecahkan persoalan makna dan nilai, yaitu kecerdasan untuk menempatkan prilaku dan hidup kita dalam konteks makna yang lebih 
luas dan kaya, kecerdasan untuk menilai bahwa tindakan atau jalan hidup seseorang lebih bermakna dibandingkan dengan yang lain.

Kecerdasan spiritual di MA Manbaul Huda yaitu berhubungan dengan perasaan batiniyah atau keagamaan, yang dapat menjadikan seseorang sadar diri dan menentukan makna, nilai, moral serta cinta terhadap sesama makhluk, karena kecerdasan spiritual disini untuk meraih sikap akhlakul karimah berdasarkan tuntunan agama. Hal ini sejalan dengan pendapatnya Ary Ginanjar Agustian (2001) yang mengungkapkan bahwa kecerdasan spirtual adalah kemampuan untuk memberi makna ibadah terhadap setiap prilaku dan kegiatan, melalui langkah-langkah dan pemikiran yang bersifat fitrah menuju manusia yang seuthnya (hanif), dan memiliki pola pemkiran tauhid (iternalistik), serta beprinsip hanya karena Allah.

Kecerdasan spiritual di MA Manbaul Huda ditempuh melalui pengamalan-pengamalan, baik yang berhubungan dengan Allah (Hablu minAlab) ataupun berhubungan dengan makhluk-Nya (Hablu minannas). Kecerdasan spiritual di MA Manbaul Huda merupakan implementasi dari kurikulum 2013, karena itu para guru bukan hanya sekedar mencerdaskan intelektual peserta didik saja, akan tetapi juga bertugas mengembangkan kecerdasan emosional dan spiritual peserta didik.

Manusia sebagai makhluk ciptaan Allah yang diberikan kesempurnaan dan kelebihan dibanding makhluk lainnya. Manusia diberikan akal untuk berfikir, perasaan dan nafsu, maka sepatutnya mempunyai akhlak yang baik terhadap Allah. Setelah melakukan wawancara dengan Kepala Sekolah dan Guru bidang Pendidikan Agama Islam di MA Manbaul Huda bahwa pengamalan-pengamalan yang berhubungan dengan Allah (Hablu minAllab) adalah Shalat dhuhur berjamaah, shalat sunnah dhuha, dzikir, puasa sunnah, zakat, dan membaca alQur'an. Selain pengamalan yang berhubungan dengan Allah (Hablu minAllah) juga ada beberapa pengamalan yang berhubungan dengan sesama makhluk-Nya (Hablu minanas) yang mengandung kecerdasan spiritual diantaranya yaitu : etika, tatakrama dan sopan santun, bersilaturahmi, menjaga kebersihan lingkungan, disiplin waktu dan menjaga kesehatan.

Adapun indicator kecerdasan spiritual diantaranya yaitu memiliki visi, merasakan kehadiran Allah, berdzikir dan berdo'a, memiliki kualitas sabar, cenderung pada kebaikan, memiliki empati, berjiwa besar dan selalu bahagia melayani (Tasmara, 2001). Orang yang mempunyai kecerdasan spiritual, ketika menghadapi persoalan dalam hidupnya, tidak hanya dihadapi dan dipecakan dengan rasional dan emosional saja,aka tetapi ia menghubungkannya dengan makna kehidupan secara spiritual dengan demikian langkah-langkahnya lebih matang dan bermakna dalam kehidupan.

2. Pembelajaran Pendidikan Agama Islam

Pelajaran Pendidikan Agama Islam di MA Manbaul Huda merupakan kumpulan dari berbagai bidang mata pelajaran didalamnya yaitu akidah akhlak, qurdis, fikih dan sejarah kebudayaan Islam. Masing-masing mata pelajaran tersebut pada dasarnya saling terkait, isi mengisi dan melengkapi.

Pendidikan agama Islam di MA Manbaul Huda Cisambeng Palasah Majalengka adalah dengan membina peserta didik untuk mampu memahami materi-materi ajaran agama Islam secara menyeluruh. Hal ini senada dengan pendapat M. Quraish Shihab yang mengungkapkan bahwa keuniversalan atau kekaffahan ajaran Islam dari aspek pengguna atau objek, materi dan dimensi ajaran Islam juga bersifat universal yang meliputi bidang keimanan, ibadah, akhlak, ekonomi, sosial, budaya, politik, keilmuan dan sains, psikologi, kesehatan dan sebagainya (M. 
Quraish Shihab 1993). Maka dari itu pemahama materi ajar tersebut sudah seharusnya menyentuh semua komponen, karena jika hanya dipahami dari satu aspek saja Pendidikan Agama Islam terasa pincang dan tidak utuh.

3. Pengembangan Kecedasan Spiritual Melalui Mata Pelajaran Pendidikan Agama Islam

Pengembangan kecerdasan spiritual melalui pendidikan agama Islam pada peserta didik di MA Manbaul Huda Cisambeng Palasah Majalengka dengan beragam upaya: Pertama, pendekatan pengembangan kecerdasan spiritual yang dilakukan di MA Manbaul Huda yaitu dengan pendekatan teladan yang baik terhadap peseta didik, karena dengan pendekatan teladan ini peseta didik dapat melakukan tata tertib sekolah dengan baik. Kedua, strategi pengembagan kecerdasan spiritual melalui mata pelajaran agama islam pada peserta didk yang di gunakan di MA Manbaul Huda Cisambeng yaitu melalui nilai-nilai pendidikan islam dan aktivitas keagamaan. Ketiga, Metode pengebangan spiritual di MA Manbaul Huda yaitu diantaranya dengan menggunakan metode pebiasaan. Jadi, peserta didik dibiasakan mengkuti rankaia kegiatan atau aktivits keagaman yang ada di MA Manbaul Huda, dengan metode pembiasaan peserta didik akan lebih mudah diarahkan karena sudah terbiasa. Intinya ingin membiasakan hal-hal kebajikan diantaranya yaitu tentang keagamaan. Keempat, Manfaat atau dampaknya pegembangan kecerdasan spiritual melalui mata pelajaran pendidikan agama Islam pada peserta ddik di MA Manbaul Huda yaitu dalam menjalani hidupnya karena segala sesuatu yang dikerjakan berorientasi kepada kemaslahatan dan mencari keridhaan Allah.

\section{Simpulan}

Secara umum kecerdasan spiritual di MA Manbaul Huda berada pada tingkat menengah dikarenakan masih seimbang antara peserta didik yang taat dan melanggar tata tertib sekolah. Pembelajaran pendidikan agama Islam di MA Manbaul Huda dengan membina peserta didik untuk mampu memahami materi-materi ajaran agama Islam secara menyeluruh. Maka dari itu Pendidikan Agama Islam di Madrasah Aliyah di pecah kedalam beberapa mata pelajaran seperti Al-Qur'an Hadits, Akidah Akhlak, fikih dan Sejarah Kebudaaan Islam. Pengembangan kecerdasan spiritual melalui pendidikan agama Islam yaitu melalui pendekatan, strategi, metode dan manfaat atau dampak bagi peserta didik di MA Manbaul Huda Cisambeng Palasah Majalengka.

\section{Daftar Pustaka}

Agustian, Ary Ginanjar. (2001). Rahasia Sukses Membangun Kecerdasan Emosi dan Spiritual ESQ, Jakarta : Arga.

Hasanah, U. (2016). Pengembangan Kecerdasan Jamak pada Anak Usia Dini. Jurnal STAIN Jurai Metro Lampung, 4(1).

Komara, Endang. (2018). Penguatan Pendidikan Karakter dan Pembelajaran Abad 21. Sipatahoenan. 4 (1).

Kurniawan, Asep. (2018). Metodologi Penelitian Pendidikan. Bandung: Remaja Rosdakarya.

Miles, Matthew B and A. Michael Huberman. (2007). Qualitative Data Analysis (terjemah). Jakarta : UI Press.

Moleong, Lexy. (2002). Metodologi Penelitian Kualitatif. Bandung: PT. Remaja Rosda Karya.

Rahawai, Ulfa. (2016). Pengembangan Kecerdasan Spiritual Santri. Jurnal Penelitian, 10(1)..

Shihab, M. Quraish. (1993). Membumikan Al-Qur'an. Bandung: Mizan Cet IV.

Tasmara, Toto. (2001). Kecerdasan Ruhaniah. Gema Insani Prss: Jakarta.

Zohar, Danah dan Ian Marshall. (2007). SQ Kecerdasan Spiritual. Bandung: Mizan Pustaka. 